\title{
Susceptibility to Melampsora Leaf Rust of Poplar Clones From Diverse Genetic Backgrounds: Effects on Photochemistry and Water Relations
}

\author{
Georgina Elena ${ }^{1}$, Jordi Fernàndez-Martínez ${ }^{1}$, Massimo Zacchini ${ }^{2}$, Assumpció Moret ${ }^{1} \&$ Isabel Fleck $^{1}$ \\ ${ }^{1}$ Unitat Fisiologia Vegetal, Departament Biologia Vegetal, Facultat de Biologia, Universitat de Barcelona (UB), \\ Spain \\ ${ }^{2}$ Istituto di Biologia Agroambientale e Forestale-CNR, Italy \\ Correspondence: Isabel Fleck, Unitat Fisiologia Vegetal, Departament Biologia Vegetal, Facultat de Biologia, \\ Universitat de Barcelona (UB), Spain. E-mail: ifleck@ub.edu
}

Received: January 26, 2014 Accepted: February 27, 2014 Online Published: March 6, 2014

doi:10.5539/jps.v3n2p1 URL: http://dx.doi.org/10.5539/jps.v3n2p1

\begin{abstract}
The selection of resistant genotypes is the most appropriate approach in the prevention of the reduction of biomass and mortality caused by rust infection in poplar plantations. Thus, it is pertinent that we improve our understanding of the consequences that this fungal disease has on leaf physiology. Here, we studied the susceptibility to Melampsora rust in three different poplar clones of commercial interest: Lux clone - Populus deltoides Batr. (cottonwood) and Luisa Avanzo and Adige clones - both Populus $\times$ canadensis Mönch. The most susceptible clone to the infection was L. Avanzo whereas Lux and especially Adige were only slightly affected. The propagation of the disease was very rapid in L. Avanzo; their leaves showed a high incidence and severity of the disease in early and advanced stages of infection as was clearly evidenced by the degree of infection. Infected leaves of L. Avanzo were shown to have drought impaired water relations during summer as reflected by the marked decline in the relative water content (RWC). Chlorophyll fluorescence imaging revealed heterogeneity of the effect of the pathogen in the leaves, and areas with pustules showed low maximum quantum yield $(\mathrm{Fv} / \mathrm{Fm})$ and PSII quantum yield $\left(\Phi_{\mathrm{PSII}}\right)$ values, indicative of strong photoinhibition. In L. Avanzo, with a greater pustule density, rust provoked a decline in whole leaf photochemistry as indicated by $\mathrm{Fv} / \mathrm{Fm}$ and photochemical reflectance index (PRI) results. Leaf structural parameters were not affected by the disease but results in L. Avanzo and Lux showed higher leaf mass per area (LMA) and higher leaf density (D) indicating an adaptation to increasing summer drought. In all clones, the effect of the pathogen was reflected in lower leaf chlorophyll content.
\end{abstract}

Keywords: Populus spp., Chlorophyll fluorescence, Chlorophyll content, Radiometric index

\section{Introduction}

Rust infection caused by species of the genus Melampsora Cast. (Basidiomycota, Uredinales, Melampsoraceae) is one of the most widespread and devastating diseases in poplars, willows and pines (Pinon \& Frey, 2005; Royle \& Hubbes, 1992; Vialle et al., 2011).

Melampsora spp. depends on the host tissues for their development, proliferation and reproduction. The fungus invades host cells, depleting their sugars and nutrients, thereby producing a decrease in stem growth, premature defoliation and predisposition to attack by insects and secondary pathogens, such as Cytospora or Dothichiza, and in some cases, it may cause plant death (Newcombe et al., 2001; Wang \& van der Kamp, 1992). The life cycle of some Melampsora species is completed by infection of poplars and coniferous hosts (Feau et al., 2007). During the summer, urediniospores are produced in yellow-orange pustules (uredinia) on the underside of Populus spp. leaves. These spores serve as the inoculum to spread the disease across Populus spp. Teliospores are produced in late summer and overwinter on the underside of dead poplar leaves on the ground (Torres, 1998). The intensive cultivation of poplars due to their high growth potential, their use in renewable energy systems (Scholz \& Ellerbrock, 2002), their capacity to capture atmospheric $\mathrm{CO}_{2}$ (Isebrand \& Karnosky, 2001) and to remediate metal pollution in soils and water (Fernàndez et al., 2012) has made them susceptible to many pathogens (Gérard et al., 2006). Moreover, stands are even-aged and monoclonal and the number of cultivars planted in a given region is limited. Simplistic monoclonal and intensive breeding, combined with the obviously high adaptive potential of Melampsora spp., have led to successive resistance breakdowns. As they do not have a 
secondary line of defence, most cultivars have been exposed to the epidemic spread of newly emerged virulent strains of the fungus (Frey et al., 2005).

In order to prevent the harmful effects on plant productivity brought about by infection by Melampsora spp., the cultivation of hybrids for their resistance to pathogens and for their wood quality highly regarded by growers is a standard practice (Newcombe et al., 1996). Lux clone - Populus deltoides Batr. (cottonwood) and Luisa Avanzo and Adige clones - both Populus $\times$ canadensis Mönch. were selected on the basis of their relevance as crops and because they respond differently to biotic and abiotic constraints. L. Avanzo and Adige are highly resistant to mosaic virus infections, whereas Lux is sensitive; the latter is tolerant to infection by the fungus Marsonnina brunnea, whereas Adige has a low tolerance and L. Avanzo is sensitive. L. Avanzo can withstand windy conditions, while Adige is less capable of doing so and Lux is sensitive to such conditions (Facciotto \& Frison, 1999).

The functional characteristics of leaves can be modified by environmental and biotic stresses (Niinemets, 2001). Direct measurements of photosynthetic parameters and other aspects of primary metabolism have not yet been reported for poplars with pathogen infections (Major et al., 2010). Foliar pathogens can reduce net $\mathrm{CO}_{2}$ assimilation (Hajji et al., 2009) by affecting stomatal conductance (Pinkard \& Mohammed, 2006) and chlorophyll decay (Holloway et al., 1992). Furthermore, the effects of foliar pathogens on plant water relations and the consequences for the crop water-use efficiency (WUE) have recently been reviewed (Grimmer et al., 2012).

The aim of this study was to determine the susceptibility to Melampsora infection in the selected poplar clones. The analysis of rust incidence (number of infected leaves per tree and number of infected trees per genotype) and severity (expressed as the degree of infection in an individual in function of the percentage of affected leaf area) allowed for the observation of the propagation of the disease in the different clones.

Another aim was to characterize the effect of the disease on physiological parameters related to photosynthetic processes and to leaf water relations in early and advanced stages of the infection during the summer. The use of chlorophyll fluorescence imaging and leaf reflectance indices allowed for a non-destructive evaluation. Chlorophyll fluorescence imaging has been used during biotic stress (Pineda et al., 2011) and provides information on electron transport characteristics both in whole leaves and in specific leaf areas affected by fungal infection.

Determination of the susceptibility to leaf rust and its effect on physiology can help to identify the most resistant clones to this infection and the most suitable ones for multiple ecological services.

\section{Materials and Methods}

\subsection{Experimental Site and Plant Material}

Poplar clones were selected from a collection of fifty clones established since 2001 in the IBAF-Institute experimental field near Rome in the Tevere valley. This area has an alluvial soil type. The climate is Mediterranean with cold winters, cool wet springs and autumns, and hot dry summers. The area registers a mean annual temperature of $13-14^{\circ} \mathrm{C}$, and an annual rainfall of 500-700 mm. Three poplar clones from different genetic backgrounds were used: Lux clone - Populus deltoides Batr. (cottonwood), which was successfully introduced into Europe from North America; and Luisa Avanzo and Adige clones - both Populus $\times$ canadensis Mönch., a hybrid from Populus deltoides and Populus nigra. Populus nigra, is native European taxon. All clones were female. Each clone was represented by 10-30 individuals in single plots.

\subsection{Sampling}

Sampling for the purpose of physiological measurements was performed in mid-July (a period when the Melampsora spp. uredinia are produced on the Populus leaves) and mid-September (after the disease has been able to develop over the summer). Climatic parameters during the study are shown in Table 1. June was relatively humid with elevated temperatures with respect to the period of sampling in July which was in contrast dry with even higher temperatures. Conditions in August were similar to those of July. In September, just before sampling, the temperatures decreased while precipitation increased markedly. All measurements were recorded on 3 randomly selected 8-years old individuals per clone in healthy leaves (control) and leaves that showed Melampsora sp. pustules (infected leaves). In both cases, leaves were fully expanded, South-oriented and collected at 2 to $4 \mathrm{~m}$ height from the base of the tree. Taking into account the different degrees of infection in each leaf throughout the whole plant, measurements on the infected leaves were recorded on those showing the average degree of severity of the measured clone. Total chlorophyll content and radiometric measurements were obtained at the IBAF-Institute experimental fields at $13.30-16.30 \mathrm{~h}$ local time. Leaf structural, hydric and 
imaging fluorescence measurements were analysed in the IBAF laboratories.

Table 1. Climatological data from the meteorological station closest to the site of the study. The first sampling corresponds to July $11^{\text {th }}$ and the second sampling to the Sepember $11^{\text {th }}$

\begin{tabular}{|c|c|c|c|c|c|c|c|c|c|c|c|}
\hline & June $1^{\text {st }}$ & June $11^{\text {th }}$ & June $21^{\text {st }}$ & July $1^{\text {st }}$ & July $11^{\text {th }}$ & July $21^{\text {st }}$ & August $1^{\text {st }}$ & August $11^{\text {th }}$ & August $21^{\text {st }}$ & September $1^{\text {st }}$ & September $11^{\text {th }}$ \\
\hline $\begin{array}{l}\text { Precipitation } \\
\qquad(\mathrm{mm})\end{array}$ & 41.2 & 8.8 & 12.2 & 10.4 & 0.2 & $\mathbf{0}$ & $\mathbf{0}$ & 2 & 12.2 & 0.4 & 65.8 \\
\hline $\begin{array}{c}\text { Radiation } \\
\left(\mathbf{k J} \cdot \mathrm{m}^{-2}\right)\end{array}$ & 25365 & 23795 & 25501 & 27367 & 27160 & 30858 & 27138 & 27463 & 24989 & 20765 & 15330 \\
\hline $\mathrm{T} \max \left({ }^{\circ} \mathrm{C}\right)$ & 28.7 & 29.7 & 30 & 34.6 & 36.4 & 35.6 & 33.5 & 36.5 & 35.9 & 31 & 27.3 \\
\hline $\mathrm{T} \min \left({ }^{\circ} \mathrm{C}\right)$ & 12.4 & 14.3 & 12.8 & 17.5 & 19 & 15.8 & 16.4 & 17.8 & 18 & 17.1 & 14.6 \\
\hline
\end{tabular}

\subsection{Incidence and Severity of Melampsora rust}

We evaluated the incidence of the pathogen first on the basis of the percentage of individuals of each clone showing visual symptoms of the disease. Then the incidence in each individual was evaluated as a percentage of the number of infected leaves (presence of pustules). Fifteen leaves were selected at random in an individual and in total 3 individuals per clone were evaluated. Severity was considered as the degree of the infection in an individual. This parameter was determined in 3 plants per clone. For each individual, we examined a total of 24 leaves from different orientations and plant height to make sampling as representative as possible. Three leaves each were taken from 8 different points on the tree: facing North, South, East and West, and from the base of the tree $(2 \mathrm{~m}$ from the soil surface) and from the top of the tree. The degree of severity in each leaf was established from the percentage of leaf area covered by Melampsora rust, as shown in Table 2. For each clone, different severity degrees were established by calculating the percentage of leaves that exhibited each degree of severity in each individual.

Table 2. Degrees of severity of the foliar infection caused by Melampsora sp.

\begin{tabular}{ccc}
\hline Degree of severity & \% Affected leaf area & Infection level \\
\hline 1 & 0 & Absent \\
1.5 & $<1$ & Traces \\
2 & $1-5$ & Mild \\
3 & $6-25$ & Moderate \\
4 & $26-50$ & Severe \\
5 & $>50$ & Very severe \\
\hline
\end{tabular}

The different percentages of affected area correspond to a degree of severity.

\subsection{Chlorophyll Fluorescence Imaging}

Chlorophyll fluorescence was recorded with the pulse-amplitude-modulated chlorophyll fluorometer Imaging-PAM (MICRO-version (Walz, Effeltrich, Germany)) operated using the Imaging Win v.2.21d (Heinz Walz) software. Chlorophyll parameters were obtained for one squared image area of $26 \times 34 \mathrm{~mm}^{2}$ per leaf. After 40 minutes dark-adaptation, minimum $\left(\mathrm{F}_{\mathrm{o}}\right)$ and maximum fluorescence $(\mathrm{Fm})$, and maximum quantum yield of PSII photochemistry $\left(F_{v} / F_{m}\right)$ (equivalent to $\left.\left(F_{m}-F_{o}\right) / F_{m}\right)$ were obtained. Subsequently, the light-adapted components of chlorophyll fluorescence (minimum fluorescence yield $\left(\mathrm{F}^{\prime}{ }_{\mathrm{o}}\right)$, maximum fluorescence yield $\left(\mathrm{F}_{\mathrm{m}}{ }_{\mathrm{m}}\right)$ and quantum yield of photosystem II ( $\Phi_{\mathrm{PSII}}$; equivalent to $\left.\left(\mathrm{F}_{\mathrm{m}}{ }_{\mathrm{m}}-\mathrm{F}\right) / \mathrm{F}{ }_{\mathrm{m}}\right)$ ) (Genty et al., 1989$)$ were obtained after five minutes of light adaptation with an incident actinic light of $300 \mu \mathrm{mol} \mathrm{m} \mathrm{m}^{-2} \mathrm{~s}^{-1}$ (Pietrini et al., 2010). Measurements were performed in 3 controls and in 3 infected leaves for 3 individuals of each clone. They were also performed on pustules and in non-affected areas of infected leaves. 


\subsection{Relative Water Content and Leaf Structural Parameters}

For all analyses, relative water content (RWC) was measured at midday on 3 infected and 3 control leaves of the 3 selected plants per clone. RWC was calculated as $\left[\left(\mathrm{M}_{\mathrm{f}}-\mathrm{M}_{\mathrm{d}}\right) /\left(\mathrm{M}_{\mathrm{fs}}-\mathrm{M}_{\mathrm{d}}\right) \cdot 100\right]$, with $\mathrm{M}_{\mathrm{f}}$ being plant fresh mass; $\mathrm{M}_{\mathrm{fs}}$, plant fresh saturated mass (after rehydrating samples for $24 \mathrm{~h}$ in the dark at $4^{\circ} \mathrm{C}$ ); and $\mathrm{M}_{\mathrm{d}}$, plant dry mass (after oven-drying samples at $65^{\circ} \mathrm{C}$ until a constant weight was achieved). Leaf area (LA) was determined with a CI 2003 Laser Leaf Area Meter (CI-203) (CID, Inc., Camas, WA 98607, USA). Leaf mass per area (LMA) was calculated as $\mathrm{M}_{\mathrm{d}} / \mathrm{LA}$ and its components Thickness and Density were calculated as $\mathrm{M}_{\mathrm{f}} / \mathrm{LA}$ and $\left[\left(\mathrm{M}_{\mathrm{d}} / \mathrm{M}_{\mathrm{f}}\right) \cdot 100\right]$ respectively (Dijkstra, 1989).

\subsection{Leaf reflectance Indices and Total Chlorophyll Content}

Leaf reflectance was measured at midday in situ on 3 infected and 3 control South-oriented leaves for 3 individuals of each clone (the same plants for all analyses) with a portable spectral analysis system with artificial light (USB4000, Oceanoptics), operated with the Spectrasuite (Oceanoptics) software. One measurement was calculated as an integration of ten scans (integration time $50 \mathrm{~ms}$ ). The photochemical reflectance index (PRI) and the water index (WI) were derived from the spectra. PRI was calculated as $\left[\left(R_{531}-R_{570}\right) /\left(R_{531}+R_{570}\right)\right]$, where $R_{n}$ is the reflectance at $n \mathrm{~nm}$ (Peñuelas et al., 1995). WI was calculated as $\left(\mathrm{R}_{900} / \mathrm{R}_{970}\right)$, where reflectance at $970 \mathrm{~nm}$ is associated with water absorption, and $900 \mathrm{~nm}$ is a reference wavelength (Peñuelas et al., 1993). For methodological reasons PRI and WI results obtained in July or September could not be compared (Peñuelas et al., 1995). Total chlorophyll content was measured with a leaf chlorophyll meter (SPAD, Minolta, Osaka, Japan) on 8 infected and 8 control leaves of 3 plants per clone.

\subsection{Statistical Analysis}

All statistical procedures were performed using Statgraphics for Windows (Statgraphics v. 15.2.14, Statpoint Inc., Virginia, USA). Analysis of variance (ANOVA) was used to test the main effects against appropriate error terms between treatments (leaf types: control, infected), clones and time (July, September) on the measured parameters. A multiple comparison test of the means was carried out using the Tukey HSD post-hoc test. Statistical significance was set at $\mathrm{p} \leq 0.05$.

\section{Results}

\subsection{Incidence and Severity of the Infection by Melampsora sp.}

In L. Avanzo the incidence of the infection originated by Melampsora sp. expressed as a percentage of individuals showing symptoms of infection was approximately twice as much as in Lux and Adige individuals during July (Table 3). In September, all individuals of L. Avanzo and Lux were infected while only $20 \%$ of the individuals of Adige showed symptoms. In July, the incidence of infection expressed as percentage of affected leaves was more than double in L. Avanzo that of Lux and Adige. In September, all leaves of L. Avanzo were infected; in Lux most leaves showed signs of the disease and in Adige only around a $16 \%$ of leaves showed symptoms. In July, $61 \%$ of L. Avanzo leaves were infected and presented a degree of severity between 2 and 3 while in September, $86 \%$ of leaves were infected and showed a degree of severity between 4 and 5 (Table 4). In July, $83 \%$ of Lux leaves were infected, which decreased to $68 \%$ in September. The degree of severity ranged from between 1 and 1.5. Most Adige leaves were infected during the study period with a degree of severity of 1 .

Table 3. Incidence of Melampsora infection in July and September

\begin{tabular}{ccccc}
\hline & \multicolumn{4}{c}{ Incidence of infection } \\
\cline { 2 - 5 } & \multicolumn{2}{c}{$\%$ individuals } & \multicolumn{2}{c}{$\%$ leaves } \\
\cline { 2 - 5 } & July & September & July & September \\
\hline L. Avanzo & 91.7 & 100 & $53.3 \pm 7.7$ & $100.0 \pm 0.0$ \\
Lux & 41.2 & 100 & $17.8 \pm 2.2$ & $73.3 \pm 26.7$ \\
Adige & 50 & 20 & $17.8 \pm 5.9$ & $15.6 \pm 2.2$
\end{tabular}

The incidence is expressed as a percentage of infected individuals and as a percentage of the number of infected leaves of 45 randomly selected leaves of 3 infected individuals ( 15 per individual) per clone expressed as mean $\pm \mathrm{SE}$. 
Table 4. Percentage of infected leaves showing the different degrees of severity in L. Avanzo, Lux and Adige clones

\begin{tabular}{ccccccc}
\hline & \multicolumn{5}{c}{ July } \\
\cline { 2 - 7 } $\begin{array}{c}\text { Degree of Rust } \\
\text { Severity }\end{array}$ & L. Avanzo & Lux & Adige & L. Avanzo & Lux & Adige \\
\cline { 2 - 7 } & 0 & $36.1 \pm 9.1$ & $63.9 \pm 7.7$ & 0 & $23.6 \pm 17.7$ & $88.9 \pm 3.7$ \\
1 & $16.7 \pm 8.7$ & $47.2 \pm 6.1$ & $30.6 \pm 6.9$ & 0 & $44.4 \pm 2.8$ & $11.1 \pm 3.7$ \\
1.5 & $23.6 \pm 11.4$ & $16.7 \pm 9.6$ & $5.6 \pm 1.4$ & 0 & $15.3 \pm 7.7$ & 0 \\
2 & $37.5 \pm 9.6$ & 0 & 0 & $19.4 \pm 2.8$ & $13.9 \pm 7.4$ & 0 \\
3 & $18.1 \pm 12.3$ & 0 & 0 & $45.8 \pm 7.2$ & $2.8 \pm 2.8$ & 0 \\
4 & $4.2 \pm 2.4$ & 0 & 0 & $34.7 \pm 8.5$ & 0 & 0 \\
5 & & 0 & & 0 & 0 & 0
\end{tabular}

The degree of severity was determined for each clone in 3 plants and in 24 leaves (three leaves each facing North, South, East and West, and at two different heights: one at the base ( $2 \mathrm{~m}$ from the soil surface) and the other at the top of the individuals). Values are mean $\pm \mathrm{SE}$.

\subsection{Relative Water Content (RWC) and Water Index (WI)}

No differences in RWC between the control and infected leaves were observed throughout the study except in the infected leaves of Lux, which showed a significant decrease in July (Figure $1 \mathrm{a}, \mathrm{b}$ ). In September, infected leaves of L. Avanzo and both kinds of leaf of Adige showed the lowest RWC values. The WI was highest for L. Avanzo in July especially in infected leaves (Figure $1 \mathrm{c}$ ). In September, Adige and Lux showed the lowest values (Figure 1 d). Methodological reasons did not permit the comparison between the WI results obtained in July and September.

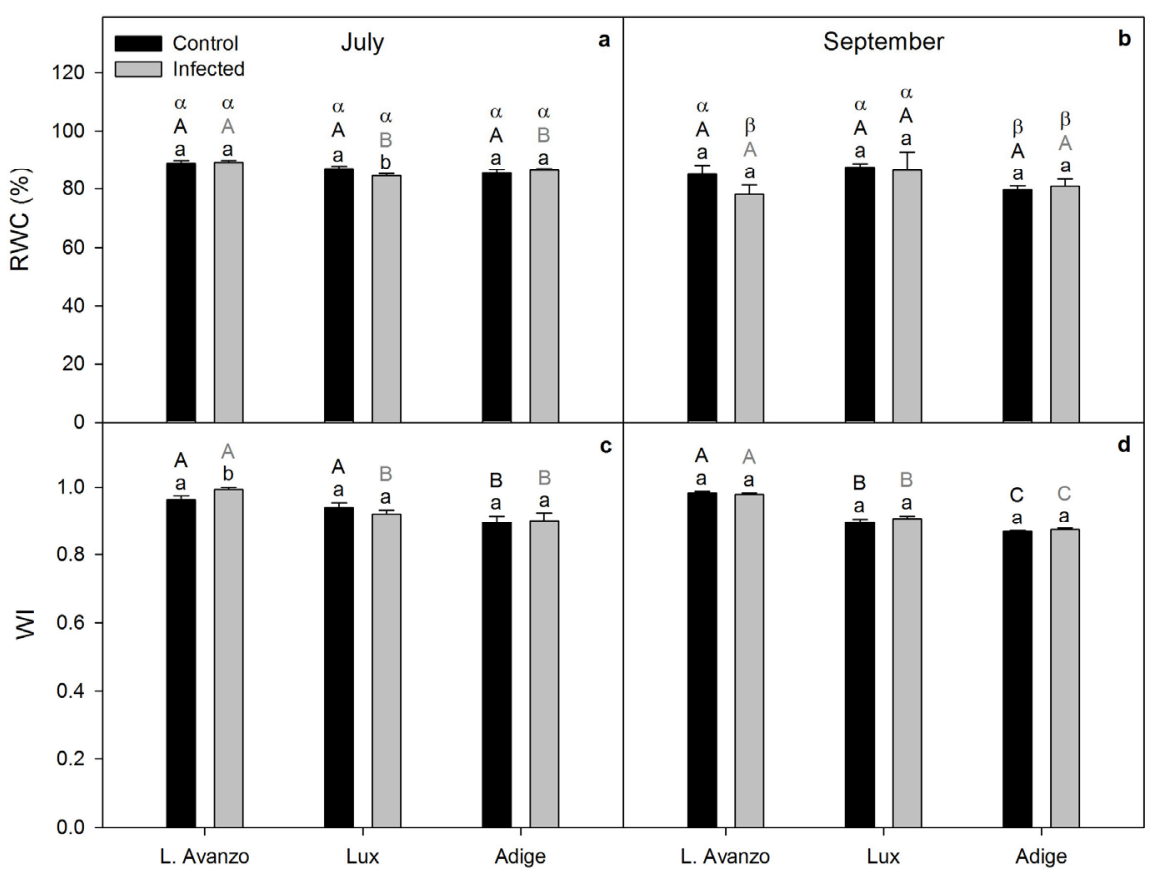

Figure $1 \mathrm{a}, \mathrm{b}$ ) Relative water content (RWC) and c,d) the radiometric index WI during the study in infected and control leaves of the different Populus spp. clones. The number of replicates was 3 leaves per types of leaf, clone and time. Significant differences $(\mathrm{p}<0.05)$ between infected and control leaves for each clone are expressed by different lower-case letters $(a, b)$. Differences between controls or between infected leaves of the different clones are expressed by different upper-case letters (A, B). Differences between times are expressed by different Greek letters $(\alpha, \beta)$. Values are mean $\pm \mathrm{SE}$ 


\subsection{Leaf Structural Parameters}

Leaf area (LA) in Lux was higher than that of the other clones (Table 5) and no differences between the control and infected leaves were observed in any of the measurements. L. Avanzo showed the greatest reduction in LA throughout the summer. Control leaves of Lux showed the highest leaf mass per area (LMA) in July, and control leaves of L. Avanzo showed the lowest LMA. For each clone, no differences in LMA were observed between the control and infected leaves. Control leaves of Lux showed the highest leaf thickness (T) in July, followed by the control leaves of Adige and then by those of L. Avanzo. Infected leaves of Lux had a lower T than did the control leaves. In September, similar values were observed in the control leaves of all three clones, whereas infected leaves in Lux and Adige showed a higher T than those of L. Avanzo. In July, leaf density (D) was highest in Lux and lowest in L. Avanzo. For each clone, the control and infected leaves showed similar D values. Comparing September with July, increases in D were observed in both kinds of leaf except for infected leaves in Adige.

Table 5. Variations in structural parameters during the study in infected and control leaves of the different Populus spp. clones: leaf area $\left(\mathrm{LA}, \mathrm{cm}^{-2}\right)$, leaf mass per area $\left(\mathrm{LMA}, \mathrm{gM}_{\mathrm{d}} \cdot \mathrm{m}^{-2}\right)$, leaf thickness $\left(\mathrm{T}, \mathrm{g} \cdot \mathrm{m}^{-2}\right)$ and leaf density (D, \%)

\begin{tabular}{cccccccc}
\hline & & L. Avanzo & L. Avanzo & Lux & Lux & Adige & Adige \\
\cline { 3 - 7 } & & Control & Infected & Control & Infected & Control & Infected \\
\hline July & LA & $45.3 \pm 4.6^{\mathrm{aA} \alpha}$ & $52.8 \pm 4.8^{\mathrm{aA} \alpha}$ & $76.6 \pm 5.1^{\mathrm{a} \alpha}$ & $85.3 \pm 10.2^{\mathrm{aB} \alpha}$ & $49.0 \pm 4.1^{\mathrm{aA} \alpha}$ & $56.9 \pm 5.0^{\mathrm{aA} \alpha}$ \\
& LMA & $66.3 \pm 4.1^{\mathrm{aA} \alpha}$ & $69.9 \pm 3.7^{\mathrm{aA} \alpha}$ & $89.8 \pm 3.0^{\mathrm{aB} \alpha}$ & $81.3 \pm 4.2^{\mathrm{aA} \alpha}$ & $77.5 \pm 2.7^{\mathrm{aC} \alpha}$ & $79.7 \pm 2.0^{\mathrm{aA} \alpha}$ \\
& T & $195.9 \pm 6.3^{\mathrm{aA} \alpha}$ & $210 \pm 8.1^{\mathrm{aA} \alpha}$ & $240.1 \pm 6.1^{\mathrm{aB} \alpha}$ & $218.4 \pm 8.1^{\mathrm{bA} \alpha}$ & $220.9 \pm 5.0^{\mathrm{a} \alpha}$ & $225.6 \pm 4.2^{\mathrm{aA} \alpha}$ \\
& D & $33.6 \pm 1.1^{\mathrm{aA} \alpha}$ & $33.2 \pm 0.8^{\mathrm{aA} \alpha}$ & $37.4 \pm 0.7^{7^{\mathrm{B} \alpha}}$ & $37.1 \pm 0.7^{\mathrm{a} \alpha}$ & $35.0 \pm 0.5^{\mathrm{aAB} \alpha}$ & $35.3 \pm 0.4^{\mathrm{aB} \alpha}$ \\
September & LA & $17.7 \pm 0.4^{\mathrm{aA} \beta}$ & $32.1 \pm 3.7^{\mathrm{aA} \beta}$ & $74.9 \pm 8.6^{\mathrm{aB} \alpha}$ & $81.6 \pm 6.0^{\mathrm{aB} \alpha}$ & $69.2 \pm 5.4^{\mathrm{aB} \alpha}$ & $47.4 \pm 5.0^{\mathrm{aC} \alpha}$ \\
& LMA & $98.0 \pm 9.8^{\mathrm{aA} \beta}$ & $83.7 \pm 2.2^{\mathrm{aA} \beta}$ & $98.3 \pm 8.4^{\mathrm{aA} \alpha}$ & $92.8 \pm 1.3^{\mathrm{aA} \alpha}$ & $94.1 \pm 10.7^{\mathrm{aA} \beta}$ & $89.5 \pm 1.0^{\mathrm{aA} \alpha}$ \\
& T & $221.3 \pm 7.8^{\mathrm{aA} \alpha}$ & $211.7 \pm 6.9^{\mathrm{aA} \alpha}$ & $217.3 \pm 7.0^{\mathrm{aA} \alpha}$ & $235.3 \pm 11.4^{\mathrm{aAB} \alpha}$ & $223.9 \pm 19.2^{\mathrm{aA} \alpha}$ & $239.1 \pm 8.0^{\mathrm{aB} \alpha}$ \\
& D & $44.1 \pm 3.2^{\mathrm{aA} \beta}$ & $40.0 \pm 2.2^{\mathrm{aA} \beta}$ & $45.1 \pm 2.4^{\mathrm{aA} \beta}$ & $39.5 \pm 1.3^{\mathrm{aA} \beta}$ & $41.8 \pm 1.3^{\mathrm{aA} \beta}$ & $37.2 \pm 1.0^{\mathrm{aA} \alpha}$ \\
\hline
\end{tabular}

The number of replicates was 3 leaves per types of leaf, clone and time. Significant differences $(p<0.05)$ between infected and control leaves for each clone are expressed by different lower-case letters $(a, b)$. Differences between the controls or between infected leaves of the different clones are expressed by different upper-case letters (A, B). Differences between times are expressed by different Greek letters $(\alpha, \beta)$. Values are mean \pm SE.

\subsection{Chlorophyll Fluorescence, Photochemical Reflectance Index (PRI) and Total Chlorophyll Content}

In all studied clones, the chlorophyll fluorescence images obtained for Fv/Fm and $\Phi$ PSII (Figure 2) revealed lower values on the areas containing fungal pustules than in areas free of the pathogen fructification. Values obtained for Fv/Fm for each clone were between 0.75-0.85 (Figure $3 \mathrm{a}, \mathrm{b}$ ). In L. Avanzo, infected leaves showed a significant decline in $\mathrm{Fv} / \mathrm{Fm}$ values from July to September with lower values than the control leaves, while Lux showed low values in September both in control and infected leaves. L. Avanzo showed the lowest PRI values in both July and September compared to the other clones, especially in the infected leaves (Figure 3c, d). Lux and Adige did not show differences between the control and infected leaves but showed lower values in September. In July, the total chlorophyll content of the infected leaves was lower than in the control leaves in L. Avanzo and Adige (Figure 3 e, f). L. Avanzo showed lower values than Lux and Adige. In September, Lux and L. Avanzo showed a decline in total chlorophyll content in infected leaves compared to the control leaves. In Adige, values were higher in comparison to those of L. Avanzo and Lux. 


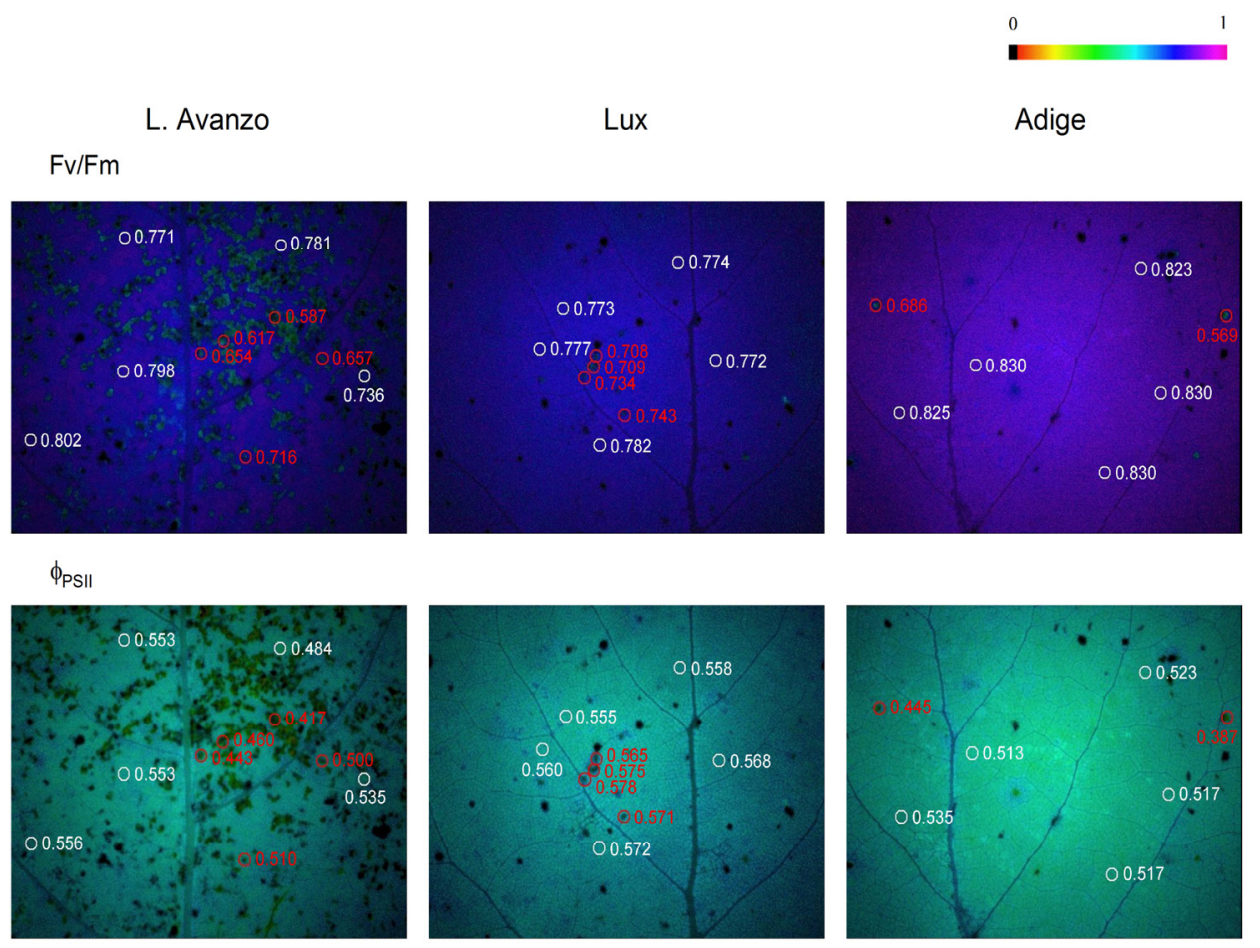

Figure 2. Chlorophyll fluorescence images of maximum quantum yield ( $\mathrm{Fv} / \mathrm{Fm})$ in a dark-adapted state and quantum yield of photosystem II photochemistry $\left(\Phi_{\mathrm{PSII}}\right)$, at steady-state with actinic illumination of $300 \mu \mathrm{E} \cdot \mathrm{m}^{-2} \cdot \mathrm{s}^{-1}$. Measurements were recorded in pustules (red circles) or not-affected areas (white circles) of infected leaves of the studied clones. The false colour code displayed at the top of the image ranges from 0 (black) to 1 (pink) 


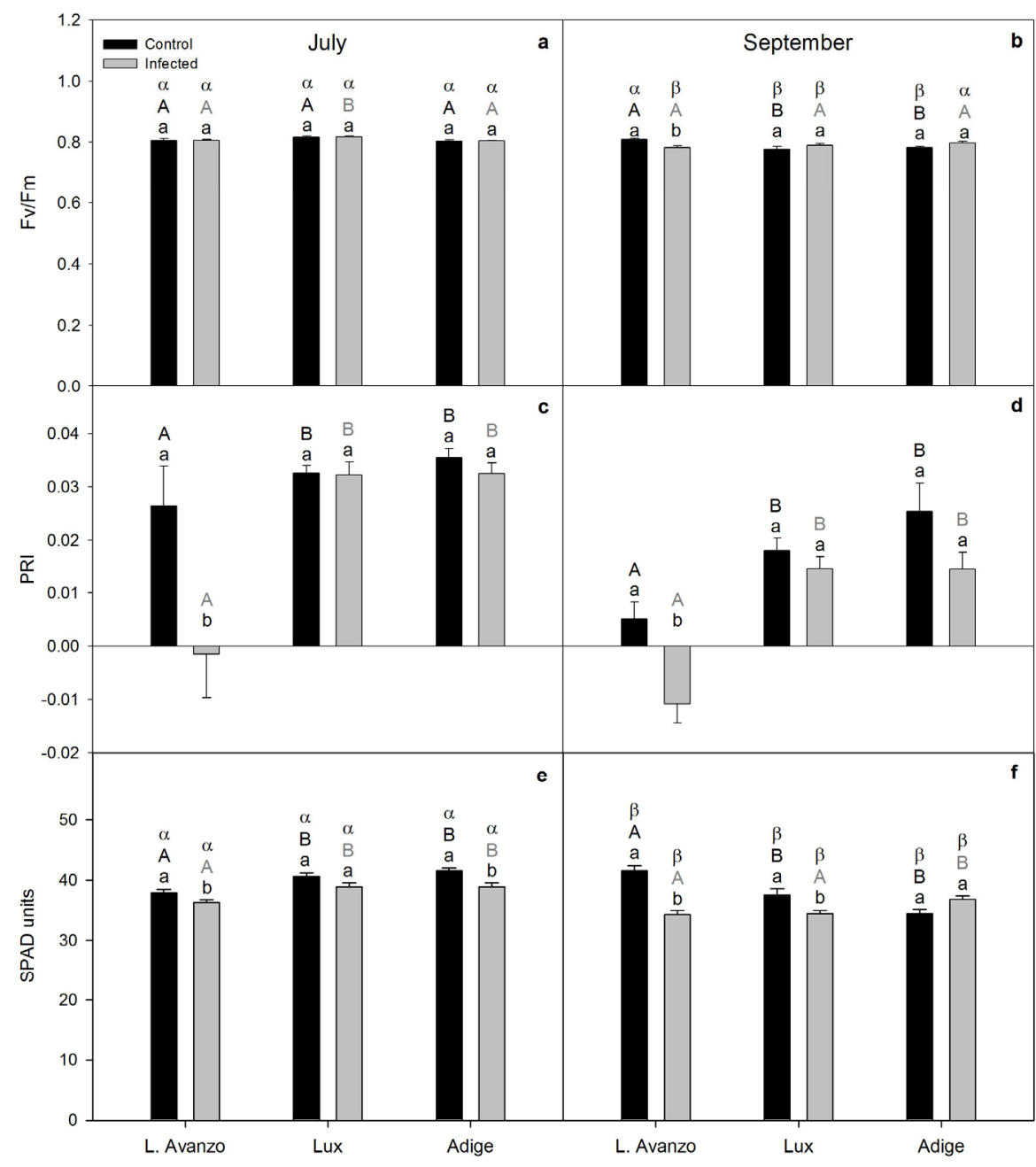

Figure $3 \mathrm{a}, \mathrm{b}$ ) Maximum quantum yield (Fv/Fm), c,d) the Radiometric index PRI and e,f) Total Chlorophyll content during the study in infected and control leaves of the different Populus spp. clones. The number of replicates was 3 leaves for $\mathrm{Fv} / \mathrm{Fm}$ and PRI and 8 leaves for chlorophyll content per types of leaf, clone and time. Significant differences $(p<0.05)$ between infected and control leaves for each clone are expressed by different lower-case letters $(\mathrm{a}, \mathrm{b})$. Differences between the controls or between infected leaves of the different clones are expressed by different upper-case letters (A, B). Differences between times are expressed by different Greek letters $(\alpha, \beta)$. Values are mean $\pm \mathrm{SE}$

\section{Discussion}

The evaluation of the effects of leaf rust on the physiological responses of poplar clones such as monitoring changes in the photochemistry processes and water relations affecting whole leaf photosynthesis can help to determine their potential in productivity programs (Widin \& Schipper, 1980).

In our study, we detected significant differences in the susceptibility to rust infection and its effect on the physiology of the selected clones during the development of their leaves.

Plants did not show signs of infection until July, thereafter L. Avanzo showed the highest level of incidence of Melampsora rust. In July, most of their individuals were infected and the percentage of affected leaves was more than double with respect to Lux and Adige. In July, the degree of severity in L. Avanzo was mild to moderate, while in September, this clone was severely affected. Other studies reported differences in the susceptibility to rust of L. Avanzo. Artificially inoculated leaf discs of two strains of M. larici-populina showed that this clone was highly resistant to the E1 strain and highly susceptible to E3 (Giorcelli et al., 1996). Frey and Pinon (1997) also observed a wide range of reactions in L. Avanzo, ranging from susceptibility to resistance, depending on the isolate. Lux, a clone considered to be resistant to the E1 and E3 strains of M. larici-populina (Giorcelli et al., 
1996) showed moderate susceptibility in this study. In July, $18 \%$ of leaves presented traces of the infection or were not infected. In September, the percentage of infection had increased to $73 \%$, while the severity remained at the same degree. In contrast to Facciotto and Frison (1999), Adige was the most resistant clone with a low incidence and degree of severity in July, and registering decreases in both parameters in September.

Productivity in fast growing species like poplars depends on water availability (Tschaplinski et al., 1994). Relative water content (RWC) and water index (WI) determinations provided information about poplar water status. In L. Avanzo, the higher RWC and WI of infected leaves in July with respect to the infected leaves of the other clones would favour the proliferation of Melampsora sp. infection in its early stages since high humidity promotes rust spore germination (Agrios, 2005), as reported for poplars (Coyle et al., 2006). Most leaves, both healthy and infected, showed elevated RWC indicating a sustained capacity to retain water during the summer. However, in L. Avanzo, RWC declined below $80 \%$ in infected leaves at the end of the summer which could be related to a possible increase in respiration and a higher limitation in photosynthetic activity (González \& González-Vilar, 2001). In Lux, infected leaves also showed lower RWC than control leaves in July but values did not fall markedly during summer drought. Foliar disease has been reported to impair stomatal closure in the dark and stomatal opening in the light thereby affecting plant $\mathrm{CO}_{2}$ assimilation and the ability to conserve water (Grimmer et al., 2012). In Adige, results for RWC and WI showed that both in July and September there was a higher susceptibility to water stress with respect to the other clones, however, no direct effects on these parameters as a result of infection were observed.

Leaf structural characteristics such as higher total and individual leaf area are related to higher productivity rates in several Populus clones (Marron, 2005). The leaf mass per area (LMA) and their two components - density (D) and thickness (T) - have been used to indicate poplar response to water stress and photosynthetic capacity. An increase in D is associated with thicker cell walls while an increase in T accounts for additional mesophyll layers (Niinemets, 2001). In spite of disease infection, no differences in D, LMA and LA were observed between control and infected clones. In September, increased sclerophylly (increases in D and LMA) and reductions in leaf transpiratory area (LA) (mainly in L. Avanzo) indicate that structural adaptations occur during summer drought.

Rust infection was not observed as having an effect on morphological parameters which contrasts with studies on defence mechanisms during pathogen infection in Populus spp. These report the strengthening of cell walls through lignin deposition (Duplessis et al., 2009) which would imply an increase in cell density (D). We only observed a decline in $\mathrm{T}$ in the early stages of Melampsora rust in Lux.

Chlorophyll fluorescence imaging provides a sensitive method for determining the impact of fungal pathogens on the photosynthetic metabolism of their hosts (Scholes \& Rolfe, 2009). Our results showed differences between pustule (rust-affected) and nearby non-affected areas of infected leaves for each clone. The leaf zones where the fungus developed fructification had lower potential efficiency of PSII photochemistry $(\mathrm{Fv} / \mathrm{Fm})$ and PSII quantum yield $\left(\Phi_{\text {PSII }}\right)$. In fact, $\mathrm{Fv} / \mathrm{Fm}$ values lower than 0.75 indicated a strong photoinhibition (Demmig-Adams \& Adams, 1993). The distribution of the mycelium of this pathogen is heterogeneous in leaves and as demonstrated by Alves et al. (2011) in eucalyptus infected by the rust fungus Puccinia psidii, photosynthesis was only reduced in diseased leaf area. The effect of infection on whole leaves depends on the ratio between infected and non-infected leaf areas. Highest pustule density was observed for L. Avanzo, followed by Lux and Adige. By September, when the disease had progressed strongly in L. Avanzo (all individuals and $100 \%$ of leaves were infected mostly with a high-severity degree of infection where leaf global $\mathrm{Fv} / \mathrm{Fm}$ values were significantly lower than those of the other clones. Lux showed lower global Fv/Fm values in September but no effects from the infection. However, whole-leaf Fv/Fm values (between 0.75 and 0.85 ) in all cases indicate that the clones were not subjected to a strong photoinhibition as a result of infection. In fact, although it can limit carbon assimilation, this disease is seldom responsible for tree death (Feau et al., 2007). The effect of the pathogen on L. Avanzo photochemistry was also apparent at high incident light intensities in the field (about $1100 \mu \mathrm{mol} \cdot \mathrm{m}^{-2} \cdot \mathrm{s}^{-1}$ ) with the lowest PRI values in both July and September compared to the other clones, PRI is related to PSII efficiency (Peñuelas et al., 1995). In general, a decline in total chlorophyll content was observed in September, especially in infected leaves of L. Avanzo and Lux in accordance with Bertamini et al. (2005). In Adige, the effect of the pathogen was not detected at the end of the summer which is in accordance with the observed reduction in the proliferation of the fungus.

Determination of susceptibility to Melampsora rust infection can help to identify the most resistant Populus clones. In this study, L. Avanzo was the most susceptible clone to rust showing a high incidence and increased severity during the summer, affecting photochemical processes, chlorophyll content and water relations. Lux and especially Adige were more tolerant to the pathogen and showed only traces of infection and slight physiological 
alterations.

\section{Acknowledgements}

This study was supported by funds from the Science and Technology Department of the Spanish Government (MCyT/FEDER, project AGL2008-00244/FOR). We wish to thank Dr. F. Pietrini, Dr. I. Trillas and Dr. C. Arenas for their helpful contributions. We would also like to thank the Service of Experimental Fields of the IBAF-CNR (Monterotondo), Servei de Camps Experimentals of Universitat de Barcelona for their technical assistance and Seán Meehan for correcting the English manuscript.

\section{References}

Agrios, G. N. (2005). Plant pathology (5th ed.). New York, NY: Elsevier Academic Press.

Alves, A. A., Guimaraes, L. M. S., Chaves, A. R. M., Damatta, F. M., \& Alfenas, A. C. (2011). Leaf gas exchange and chlorophyll a fluorescence of Eucalyptus urophylla in response to Puccinia psidii infection. Acta Physiol Plant, 33, 1831-1839. http://dx.doi.org/10.1007/s11738-011-0722-z

Bertamini, M., Malossini, U., Muthuchelian, K., \& Nedunchezhiani, N. (2005). Physiological response of field grown grapevine (Vitis vinifera L. cv. Marzemino) to grapevine leafroll-associated virus (GLRaV-1). Phytopathol Mediterr, 44, 256-265.

Coyle, D. R., Coleman, M. D., Durant, J. A., \& Newman, L. A. (2006). Multiple factors affect pest and pathogen damage on 31 Populus clones in South Carolina. Biomass Bioenergy, 30, 759-68. http://dx.doi.org/10.1016/j.biombioe.2005.07.019

Demmig-Adams, B., \& Adams, W. (1993). The xanthophyll cycle. In A. Young \& G. Britton (Eds.), Carotenoids in photosynthesis. (pp. 281-304). London, England: Chapman \& Hall. http://dx.doi.org/10.1007/978-94-011-2124-8_7

Dijkstra, P. (1989). Cause and effect of differences in specific leaf area. In H. Lambers, H. Konings \& T. L. Pons (Eds.), Causes and consequences of variation in growth rate and productivity of higher plants (pp. 125-140). The Hague, The Netherlands: SPB Academic Publishing bv.

Duplessis, S., Major, I., Martin, F., \& Seguin, A. (2009). Poplar and pathogen interactions: insights from Populus genome-wide analyses of resistance and defense gene families and gene expression profiling. CRC Crit Rev Plant Sci, 28, 309-334. http://dx.doi.org/10.1080/07352680903241063

Facciotto, G., \& Frison, G. (1999). Cloni di pioppo. In M. Fini \& G. Facciotto (Eds.), Il pioppo. (Suppl. N 4). Ermes, Bologna, Italy: Agricoltura. Retrieved from http://www.ermesagricoltura.it/Informazioni/Agricoltura/SUPPLEMENTO-N.1-Il-pioppo

Feau, N., Joly, D. L., \& Hamelin, R. C. (2007). Poplar leaf rusts: model pathogens for a model tree. Can J Bot, 85, 1127-1135. http://dx.doi.org/10.1139/B07-102

Fernàndez, J., Zacchini, M., \& Fleck, I. (2012). Photosynthetic and growth responses of Populus clones Eridano and I-214 submitted to elevated $\mathrm{Zn}$ concentrations. J Geochem Explor, http://dx.doi.org/10.1016/j.gexplo.2012.01.010

Frey, P., Gérard, P. R., Feau, N., Husson, C., \& Pinon, J. (2005). Variability and population biology of Melampsora rusts on poplars. In M. H. Pei \& A. R. McCracken (Eds.), Rust Diseases of Willow and Poplars. (pp. 63-72). Wallingford, UK: CAB International. http://dx.doi.org/10.1079/9780851999999.0063

Frey, P., \& Pinon, J. (1997). Variability in pathogenicity of Melampsora allii-populina expressed on poplar cultivars. Eur J Forest Pathol, 27, 397-407. http://dx.doi.org/10.1111/j.1439-0329.1997.tb01455.x

Genty, B., Briantais, J. M., \& Baker, N. R. (1989). The relationship between the quantum yield of photosynthetic electron transport and quenching of chlorophyll fluorescence. Biochim Biophys Acta, 990, 87-92. http://dx.doi.org/10.1016/S0304-4165(89)80016-9

Gérard, P. R., Husson, C., Pinon, J., \& Frey, P. (2006). Comparison of genetic and virulence diversity of Melampsora larici-populina populations on wild and cultivated poplar and influence of the alternate host. Phytopathology, 96, 1027-1036. http://dx.doi.org/10.1094/PHYTO-96-1027

Giorcelli, A., Vietto, L., Anselmi, N., \& Gennaro, M. (1996). Influence of clonal susceptibility, leaf age and inoculum density on infections by Melampsora larici-populina races E1 and E3. Eur $J$ For Pathol, 26, 323-331. http://dx.doi.org/10.1111/j.1439-0329.1996.tb01078.x

González, L., \& González-Vilar, M. (2001). Determination of relative water content. In M. J. Reigosa (Ed.), 
Handbook of plant ecophysiology techniques (pp. 207-212). Dordrecht, the Netherlands: Kluwer Academic Publishers.

Grimmer, M. K., Foulkes, M. J., \& Paveley, N. D. (2012). Foliar pathogenesis and plant water relations: a review. $J$ Exp Bot, 12, 4321-4331. http://dx.doi.org/10.1093/jxb/ers143

Hajji, M., Dreyer, E., \& Marcais, B. (2009). Impact of Erysiphe alphitoides on transpiration and photosynthesis in Quercus robur leaves. Eur J Plant Pathol, 125, 63-72. http://dx.doi.org/10.1007/s10658-009-9458-7

Holloway, P. J., Maclean, D. J., \& Scott, K. J. (1992). Electron transport in thylakoids isolated from barley leaves infectedby the powdery mildew fungus (Erisiphe graminis DC. ExMerat f.sp. hordei marchal). New Phytol, 120, 145-151. http://dx.doi.org/10.1111/j.1469-8137.1992.tb01067.x

Isebrand, J. G., \& Karnosky, D. F. (2001). Environtmental benefits of poplar culture. In D. A. Dickmann, I. C. Isebrand, J. Eckenwalder \& J. Richardson (Eds.), Poplar culture in North. (pp. 207-218). Ottawa, Canada: NRC Research Press.

Major, I. T., Nicole, M. C., Duplessis, S., \& Séguin, A. (2010). Photosynthetic and respiratory changes in leaves of poplar elicited by rust infection. Photosynth Res, 104, 41-48. http://dx.doi.org/10.1007/s11120-009-9507-2

Marron, N., Villar, N., Dreyer, E., Delay, D., Boudouresque, E., Petit, J. M., ... Brignolas, F. (2005). Diversity of leaf traits related to productivity in 31 Populus deltoides $\times$ Populus nigra clones. Tree Physiol, 25, 425-435. http://dx.doi.org/10.1093/treephys/25.4.425

Newcombe, G., Bradshaw, H. D., Chastagner Jr., G. A., \& Stettler, R. F. (1996). A major gene for resistance to Melampsota medusae f. Sp. deltoidae in a hybrid poplar pedigree. Am Phytopathol Soc, 86, 87-94. http://dx.doi.org/10.1094/Phyto-86-87

Newcombe, G., Ostry, M. E., Hubbes, M., Périnet, P., \& Mottet, M. J. (2001). Poplar diseases. In D. I. Dickman, J. G. Isebrands, J. E. Eckenwalder, \& J. Richardson (Eds.), Poplar culture in North America (pp. 249-276). Ottawa, Canada: NRC Research Press, National Research Council of Canada.

Niinemets, Ü. (2001). Global scale climatic controls of leaf dry mass per area, density and thickness in trees and

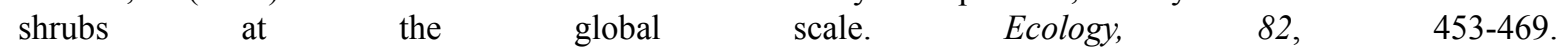
http://dx.doi.org/10.1890/0012-9658(2001)082[0453:GSCCOL]2.0.CO;2

Peñuelas, J., Filella, I., Biel, C., Serrano, L., \& Savé, R. (1993). The reflectance at the 950- $970 \mathrm{~nm}$ region as an indicador of plant water status. Int $J$ Remote Sens, 14, 1887-1905. http://dx.doi.org/10.1080/01431169308954010

Peñuelas, J., Filella, I., \& Gamon, J. A. (1995). Assessment of photosynthetic radiation-use efficiency with spectral reflectance. New Phytol, 131, 291-296. http://dx.doi.org/10.1111/j.1469-8137.1995.tb03064.x

Pietrini, F., Zacchini, M., Iori, V., Pietrosanti, L., Ferretti, M., \& Massacci, A. (2010). Spatial distribution of cadmium in leaves and its impact on photosynthesis: examples of different strategies in willow and poplar clones. Plant Biol, 12, 355-363. http://dx.doi.org/10.1111/j.1438-8677.2009.00258.x

Pineda, M., Olejníckova, J., Cséfalvay, L., \& Baron, M. (2011). Tracking viral movement in plants by means of

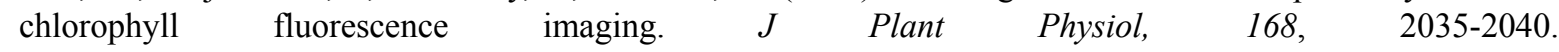
http://dx.doi.org/10.1016/j.jplph.2011.06.013

Pinkard, E. A., \& Mohammed, C. L. (2006). Photosynthesis of Eucalyptus globulus with Mycosphaerella leaf disease. New Phytol, 170, 119-127. http://dx.doi.org/10.1111/j.1469-8137.2006.01645.x

Pinon, J., \& Frey, P. (2005). Interactions between poplar clones and Melampsora larici-populina populations and their implications for breeding for durable resistance In M. H. Pei \& A. R. McCracken (Eds.), Rust Diseases of Willow and Poplars. (pp. 139-154) Wallingford, UK: CAB International. http://dx.doi.org/10.1079/9780851999999.0139

Royle, D. J., \& Hubbes, M. (1992). Diseases and pests in energy crop plantations. Biomass Bioenergy, 2, 45-54. http://dx.doi.org/10.1016/0961-9534(92)90087-7

Scholes, J. D., \& Rolfe, S. A. (2009). Chlorophyll fluorescence imaging as tool for understanding the impact of fungal diseases on plant performance: a phenomics perspective. Funct Plant Biol, 36, 880-892. http://dx.doi.org/10.1071/FP09145

Scholz, V., \& Ellerbrock, R. (2002). The growth productivity, and environmental impact of the cultivation of energy crops on sandy soil in Germany. Biomass Bioenergy, 23, 81-92. 
http://dx.doi.org/10.1016/S0961-9534(02)00036-3

Torres, J. J. (1998). Patología forestal: principales enfermedades de nuestras especies forestales (2nd ed.). Spain: Mundi-Prensa Libros, S.A.

Tschaplinski, T. J., Tuskan, G. A., \& Gunderson, C. A. (1994). Water stress tolerance of black and eastern cottonwood clones and four hybrid progeny. I. Growth, water relations and gas exchange. Can J For Res, 24, 364-371. http://dx.doi.org/10.1139/x94-049

Vialle, A., Frey, P., Hambleton, S., Bernier, L., \& Hamelin, R. (2011). Poplar rust systematics and refinement of Melampsora species delineation. Fungal Divers, 20, 227-248. http://dx.doi.org/10.1007/s13225-011-0129-6

Wang, J., \& van der Kamp, B. J. (1992). Resistance, tolerance, and yield of western black Cottonwood infected by Melampsora rust. Can J For Res, 22, 183-192. http://dx.doi.org/10.1139/x92-024

Widin, K. D., \& Schipper, A. L. (1980). Epidemiology of Melampsora medusae leaf rust of poplars in north central United States. Can J For Res, 10, 257-263. http://dx.doi.org/10.1139/x80-044

\section{Copyrights}

Copyright for this article is retained by the author(s), with first publication rights granted to the journal.

This is an open-access article distributed under the terms and conditions of the Creative Commons Attribution license (http://creativecommons.org/licenses/by/3.0/). 